\title{
Introduction: The Anti-colonial Intellectual
}

\author{
Hicham Safieddine
}

In the mid-twentieth century, national liberation movements fought fiercely against European colonialism and American imperialism. The ideological field of struggle was a highly active front in this battle. As more "Third World" countries gained formal political independence but remained subjugated economically, their Marxist-leaning intellectuals articulated theories of 'underdevelopment' that challenged liberal notions of modernisation on the one hand and Eurocentric articulations of anti-imperialism on the other. ${ }^{1}$

This translation of selected writings is an attempt to shed light on the notable contribution in this field of Arab Marxist Mahdi Amel. Amel (1936-87) was a prominent theoretician of colonialism and 'underdevelopment' in an Arab context and a long-time Lebanese Communist Party member during the era of national liberation. He also wrote on a wide range of subjects that are highly pertinent to current debates about the Arab region. They included sectarianism, political Islam, orientalism, culture and revolution, and the relationship of cultural heritage to modernity - all of which he explored through the lens of class analysis. He hailed from the Marxist-Leninist tradition and was influenced, in an undogmatic manner, by Althusser's school of thought. But above all else, he was an anti-colonial Marxist. Throughout his writings, he sought to produce a theory of Marxism that took colonial rather than capitalist social reality as its starting point. He explained underdevelopment according to colonial reality's own terms. He avoided terms like periphery or Third World, which decentred or hierarchised this reality, even if implicitly. He equally insisted on using concepts like liberation, which affirmed active and future-oriented resistance on the part of the colonised, rather than decolonisation, which conjured up a passive process of illusory return to some pre-colonial past.

1 Half a century later, their contribution to the evolution of Marxist theory is often relegated to the margins of Anglophone debates on political economy. When broached, their works tend to be summarily grouped under the rubric of dependency theory associated with a handful of authors. These authors include Fernando Cardoso and Andre Gunder Frank in Latin America, Hamza Alvi in South Asia, and Samir Amin in the Arab world. Until recently, Marx's own treatment of the colonial world has been largely ignored or reductively associated with certain concepts like the Asiatic mode of production. For a more substantial treatment, see Anderson 2010. 
Amel's centring of the colonial experience was manifest in his analytical treatment of the colonial relation. In Amel's theoretical universe, colonialism itself is the objective basis for the unity of the colonised country's social formation. It constitutes the historical framework for the development of the forces of production in colonial societies. It is an all-encompassing, rather than purely economic, relationship within which a fusion took place between the capitalist and pre-capitalist modes of production. This fusion gave rise to a new relationship of structural dependency. 'All of my inquiry', Amel wrote, 'is an attempt to define this form of dependency, and it has yielded the concept of the colonial mode of production (CoMP).' ${ }^{2}$

The CoMP is 'the form of capitalism structurally dependent on imperialism in its historical formation and contemporary development.' ${ }^{3}$ Contradictions that shape and drive class struggle under a CoMP operate at the level of the interaction of the two interdependent structures of capitalist and colonised social formations. This creates multiple and complex layers of contradictions. ${ }^{4}$

Amel set out to discern the characteristics that distinguished the CoMP from the capitalist mode of production. In the process, he produced a lexicon of terms and concepts specific to the CoMP. What might appear as conceptual shortcomings for classical Marxist thought, Amel saw as theoretical affirmations of the particularity of the colonial social formation. The CoMP, for instance, was defined by the very fact that it was prevented from developing into a full mode of production. Political instability, often cited as evidence of weak state formation or ascribed to a defective political culture, was itself a feature of the phenomenon of class substitution - rather than class revolution prevalent under the colonial mode of production and expressed in the form of frequent military coups or short-lived governments. This instability, Amel pointed out, is partly a consequence of the stability, not stagnancy, of the overall social structure as a result of the blocking of social development under the CoMP. 'Class substitution occurs within the bounds of the social structure itself without bringing about a structural change in the social mode of production' ${ }^{5}$ At the centre of class substitution under a CoMP are the petite bourgeoisie. Whereas this faction of the bourgeoisie is conceptualised by Amel as marginal

2 See Amel 2013, p. 524.

3 See Amel 199o, p. 11.

4 As Amel notes, "There is the basic contradiction that encompasses the structural contradictions in each particular structure; then there is the complication presented by the existence of a dominant structure in the unity; and finally there is a dominant contradiction, which is the primary contradiction, in the unity of contradictions in each structure'. Amel 2013, p. 529.

5 Amel 2013, p. 542. 
and 'parasitic' in the capitalist mode of production that evolved in Europe, it is nothing less than the 'centre-point of history's movement' in a colonial formation.

Another feature of CoMP is the relative lack of class differentiation. This is not a sign of underdeveloped capitalist relations, but a structural limitation of CoMP. Class struggle therefore involves the struggle for the exploited classes' very existence as a class, 'i.e. as a struggle to free up the historical process of its own class formation. Herein lies the distinction of the [class] contradiction in colonial society'. The relation of exploitation is indirect, with the principal class enemy being the colonial structure itself as opposed to a particular class. As a result, the form of class struggle in colonial society differs from the conventional form of the proletarian revolution in capitalist Europe. In colonial societies, the socialist revolution is inseparable from national liberation:

The struggle for national liberation is the sole historical form that distinguishes class struggle in the colonial [structural] formation. Whoever misses this essential point in the movement of our modern history and attempts to substitute class struggle with 'nationalist struggle' or reduces the national struggle to a purely economic struggle loses the ability to understand our historical reality and thus also [the ability] to control its transformation. ${ }^{6}$

The transition to socialism - for capitalist and colonised societies alike - necessitates the severing of this colonial relation: 'The revolution against colonialism is the only path to liberate human history.'

In 1968, Amel set out his line of thinking about the relation between colonialism and underdevelopment in a pioneering study titled 'Colonialism and Underdevelopment'. It was published as a two-part series in al-Tariq, the Lebanese Communist Party's political and intellectual journal. Both essays are translated in this anthology in full. ${ }^{7}$ They are titled respectively: 'An Attempt to Understand the Colonial Relationship' and 'The Colonial Mode of Production'. Amel would later develop his ideas into a more in-depth theorisation of the CoMP in his magnum opus titled Theoretical Prolegomena to the Study of the Impact of Socialist Thought on the National Liberation Movement. In 1972, Amel

6 Amel 2013, p. 472.

7 Editor's note: The original Arabic text of part two includes an introductory section that mostly sums up part one of Amel's study On Colonialism and Underdevelopment. Given that the first part was translated in full, the introductory section was dropped from this translation of part two. 
published the first two parts of this work, 'On Contradiction' and 'On the Colonial Mode of Production'. The third part, titled 'On the Staging of History', was put on hold. At that time, the rise of neoliberalism worldwide was accompanied in the post-Nasserist Arab world by the spread of conservative ideological currents, including a culturalist turn. This reoriented Amel's intellectual output towards what he saw as pressing problems facing Arab nationalism. In response to a Kuwait conference held in April 1974 to discuss the purported crisis of civilisational development in the Arab world, Amel lambasted the Arab national bourgeoisies for turning their own crisis of rule into a crisis of Arab civilisation as such. ${ }^{8}$ He argued that the idea - upheld by many liberals - that AraboIslamic 'cultural heritage' (turath) was potentially incompatible with modernity was itself a problem of the present, i.e. a problem of how these thinkers interpreted the past, not a problem of the past. Heritage itself was conjured up by imperialist forces in an orientalist manner that justified the latter's 'civilising mission', which to Amel's dismay was scandalously internalised by the bourgeois leadership of several national movements. ${ }^{9}$

Amel was also critical of Edward Said's portrayal of Marx's thought. Like other Marxists, Amel argued that Said, in his influential book Orientalism, fails to properly contextualise the selective passages of Marx he cites and, more significantly, treats all Western thought as a monolith without reference to its class character. This is because Said ignores the materialist basis on which Marx's thought rests and thereby denies its revolutionary novelty. Amel found it equally necessary to counter the rise of anti-intellectual 'everyday thought' in the press. In a manuscript, posthumously published and titled $A$ Critique of Everyday Thought, he identified three major categories of quotidian thought: nihilist, obscurantist, and Islamised bourgeois.

These emerging trends signalled ideological shifts in Arab bourgeois thought that took place as a result of two developments. The first was the liberal turn of certain nationalist forces in the post-Nasserist era. The second was the rise of Islam as a force in Arab politics following the Islamic revolution in Iran and the expansion of Saudi Salafism. In his critique of Islamised bourgeois thought, Amel steered clear of culturalist and idealist interpretations. For Amel, Islam's revolutionary or reactionary character must be measured in relation to its class rather than metaphysical character: 'Anyone who speaks about political Islam in a general sense without defining the particular class character of its political being - whether revolutionary or anti-revolutionary, reactionary bourgeois

8 On Amel as one of the few intellectuals to resist the culturalist trend in explaining Arab social ills, see Massad 2007, p. 20.

9 Amel expressed these views in A Crisis of Arab Civilization or a Crisis of the Arab Bourgeoisies? (Amel 2002). 
or anti-bourgeois - is speaking from a dominant bourgeois position. ${ }^{10}$ Under Amel's framework, the primary contradiction in Islam is not between belief and atheism, but between those who defer to power and those who defy it. It follows that institutionalised Islam of the ruling classes, including that of Andalusian rationalist philosopher Ibn Rushd, was often a hindrance to revolutionary change. ${ }^{11}$

The Lebanese civil war, which broke out in 1975, was another major development that influenced Amel's intellectual output. Amel examined the causes of the war and analysed sectarianism through the prism of class analysis. He is arguably the first Lebanese thinker to identify sectarianism as a strictly modern and political rather than a primordial and religious phenomenon. Amel elucidates the contradictions and crises of the Lebanese state as a simultaneously bourgeois and sectarian system of rule. Sects, Amel asserts, are not, as bourgeois thought would have it, stand-alone social formations. A sect is a determined political relation embedded in a particular political system, sectarianism. Put differently, a sect is a historically determined form of class domination particular to CoMP. The book was equally a criticism of a strand of leftist thought that fell into the trap of implicitly reproducing or confirming Lebanese bourgeois thought by granting sects an ontological existence independent of political relations.

Amel went further and exposed the falsehood of bourgeois tropes of powersharing arrangements among sects. Fair political 'participation' among sects, he argued, was a utopian slogan raised by the non-hegemonic factions of the dominant bourgeoisie in order to improve their own class position within the sectarian divisions of power. Sectarian balance is only possible through the hegemony of a particular sect, not participation of all sects. When this hegemony is threatened, the fascist solution is proposed to salvage the system, as the sectarian right-wing Kataeb party attempted to do during the civil war. Amel premonitorily warned that substituting one sectarian hegemony, Maronite, with another, say Sunni or Shia, would not alter the sectarian nature and solve the crisis but simply reproduce it. ${ }^{12}$

Amel did not survive the Lebanese civil war. He was assassinated on 18 May 1987. His elimination was part of a killing spree by sectarian Islamist forces tar-

\footnotetext{
10 See Amel 2005, p. 330.

11 In English, Ibn Rushd is commonly referred to as Averroes.

12 Amel published three major studies on the subject: Introduction into the Theory in Political Practice: An Inquiry into the Causes of the Lebanese Civil War (Amel 1979); A Gateway into Refuting Sectarian Thought: The Palestinian Cause in the Ideology of the Lebanese Bourgeoisie (Amel 1980); and On the Sectarian State (Amel 1986).
} 
geting communist intellectuals. Thirty years later, a new generation of Arab leftists that came of age during the Arab uprisings have revived his legacy in public spaces and on social media. His Arabic publications remain in print. Recent scholarly interest in the Anglophone academy has provided a preliminary peak into his thought. These studies, however, have largely remained cursory and in some cases distorted by postmodern inflections or romanticised generalisations. ${ }^{13}$ Reading Amel in his own words is a major step towards taking full and critical stock of his thought, whatever its contradictions and evolutionary transformation. Doing so would place his thought in comparative perspective to contemporary Marxist theories of colonialism and underdevelopment, rather than provincialize his contribution or use his assassination as a tool to discredit Hezbollah today in ahistorical and decontextualized accounts of the role of communist and Islamist forces in resisting Zionism.

The current collection brings for the first time to an English audience lengthy excerpts from six major works by Amel. These include the two founding texts on colonialism and underdevelopment in which Amel began to grapple with the question of dependency, his treatise on sectarianism and the state, his critique of Edward Said's analysis of Marx, his exposure of emerging Islamised bourgeois trends of thought as part of a broader critique of everyday thought, and his reflection on cultural heritage as perceived by the Arab bourgeoisies.

With over a dozen published books to Amel's credit, this collection is a long way from introducing all aspects of his thought, including his study on the staging of history. The latter offers a valuable window into the evolution of his thinking on temporality and the determinist aspects of Louis Althusser and Étienne Balibar's structuralism in which Amel discerned implicit antirevolutionary tendencies. In this and all other writings, Amel stressed the interplay of the universal and the particular. His Marxism, like that of other anti-colonial Marxists, serves as a powerful rebuttal to persistent post-colonial polemics that reduce Marxism to a provincial theory of mere European relevance or Marxist dogma steeped in Western thought. Back in Amel's days, Marxism was a major current of political action and intellectual activity in the Arab world. Reviving this thought is crucial to understanding the historical conjuncture of national liberation in Arab history that is often dismissed as a passing moment of progressive reformation or derided as a failed project of modernisation.

13 For recent studies and writings in English that specifically address Amel's work, see Frangie 2012, pp. 465-82; Sing and Younes 2013, pp. 149-91; Abu Rabi' 2004, pp. 318-43; Tohme 2012; Prashad 2014. 
Non-European Marxist thought like Amel's remains equally relevant for ongoing struggles around the world, if only as a reminder of the need to renew Marxist thought based on the concrete and particular social realities of today and the demands of existing political struggles. Amel emphasised the unifying nature of political struggle. For him, transformative rather than speculative theoretical activity, including the production of a theory of underdevelopment, was part and parcel of his political struggle. His lived experience and untimely death, briefly sketched in the following section, were as much an expression of anti-colonial struggle as were his writings. Both have yet to be fully incorporated into the legacy of national liberation thought with its triumphs and tragedies. $^{14}$

14 I wish to thank Evelyne Hamdan, Redha Hamdan, and Gilbert Achcar for their helpful comments on drafts of this introduction. 